\title{
Plant essential oils against bacteria isolated from fish: an in vitro screening and in vivo efficacy of Lippia origanoides
}

\author{
Guerino Bandeira Junior ${ }^{1}$ (D) Carine de Freitas Souza ${ }^{1}$ Matheus Dellaméa Baldissera ${ }^{1}$ \\ Sharine Nunes Descovi ${ }^{1}$ Bibiana Petri da Silveira ${ }^{2}$ Caiane Tasca ${ }^{2}$ Rosa Helena Veras Mourão ${ }^{3}$ \\ Agueda Palmira Castagna de Vargas $^{2}$ Bernardo Baldisserotto ${ }^{* *}$ (D)
}

${ }^{1}$ Programa de Pós-graduação em Farmacologia, Universidade Federal de Santa Maria (UFSM), 97105-900, Santa Maria, RS, Brasil. E-mail: bbaldisserotto@hotmail.com. *Corresponding author.

${ }^{2}$ Programa de Pós-graduação em Medicina Veterinária, Universidade Federal de Santa Maria (UFSM), Santa Maria, RS, Brasil.

${ }^{3}$ Programa de Pós-graduação em Recursos Naturais da Amazônia, Universidade Federal do Oeste do Pará (UFOPA), Santarém, PA, Brasil.

ABSTRACT: The use of natural products, such as essential oils (EOs), is a potential novel approach to treat fish bacterial infections with a lower risk of developing resistance. There has been a number of studies reporting the activity of EOs as those obtained from the species Achyrocline satureioides, Aniba parviflora, Aniba rosaeodora, Anthemis nobilis, Conobea scoparioides, Cupressus sempervirens, Illicium verum, Lippia origanoides, and Melaleuca alternifolia against bacteria. However, there are few studies investigating the effect of these EOs against fish bacteria. Therefore, the aim of this study was to evaluate the in vitro antibacterial activity of EOs against the following fish bacteria, Aeromonas hydrophila, Citrobacter freundii, and Raoultella ornithinolytica. Additionally, the in vivo antibacterial activity of the EO L. origanoides was evaluated against experimentally induced A. hydrophila infection of silver catfish (Rhamdia quelen). The EO of L. origanoides was chosen as it showed the highest in vitro antibacterial activity, with minimum inhibitory concentrations ranging from 0.2 to 0.8 $m g m L^{-1}$. This EO also presented a therapeutic success of $58.33 \%$, on a 30 day A. hydrophila infection. Therefore, we suggested that the EO of L. origanoides may be a viable alternative as a treatment for A. hydrophila infection.

Key words: Aeromonas hydrophila, antibacterial activity, silver catfish, longevity, therapeutic success.

Óleos essenciais de plantas contra bactérias isoladas de peixes: uma triagem in vitro e eficácia in vivo de Lippia origanoides

RESUMO: $O$ uso de produtos naturais, como óleos essenciais (OEs), é uma nova abordagem potencial para o tratamento de infecções bacterianas em peixes com um baixo risco de desenvolvimento de resistência. Existem estudos reportando a atividade de OEs como aqueles obtidos das espécies Achyrocline satureioides, Aniba parviflora, Aniba rosaeodora, Anthemis nobilis, Conobea scoparioides, Cupressus sempervirens, Illicium verum, Lippia origanoides e Melaleuca alternifolia contra bactérias. Porém, existem poucos estudos investigando o efeito desses OEs supracitados contra bactérias isoladas de peixes. Portanto, o objetivo desse estudo foi avaliar a atividade antibacteriana in vitro desses OEs contra bactérias isoladas de peixes (Aeromonas hydrophila, Citrobacter freundii e Raoultella ornithinolytica). Assim como avaliar a atividade antibacteriana in vivo do OE de L. origanoides contra uma infecção por A. hydrophila experimentalmente induzida em jundiá (Rhamdia quelen). O OE de L. origanoides foi escolhido porque apresentou a melhor atividade antibacteriana in vitro, com concentrações inibitórias mínimas variando de 0,2 a 0,8 $\mathrm{mg} \mathrm{mL}^{-1}$. Esse OE apresentou sucesso terapêutico de 58,33\% no dia 30 pós-infecção. Portanto, sugerimos que o OE de L. origanoides possa ser uma alternativa viável no tratamento da infecção por A. hydrophila em peixes. Palavras-chave: Aeromonas hydrophila, atividade antibacteriana, jundiá, longevidade, sucesso terapêutico.

\section{INTRODUCTION}

With the expansion of aquaculture production in recent years, fish have become exposed to adverse conditions, generating stress and consequent immunosuppression in the population. With this, the number of infections caused by opportunistic bacteria has increased, causing growth impairment, mortality, and serious economic losses for fish producers (BAKER et al., 2013). Therefore, antibiotics are commonly used to reduce and prevent the negative impact of infections caused by opportunistic bacteria. However, their incorrect and indiscriminate utilization has led to the development of multidrug resistance, environmental contamination, and fish toxicity (EL-NAHHAL et al., 2016; GRENNI et al., 2018). The silver catfish (Rhamdia quelen) is the 
most produced native fish species in south Brazil, being distributed widely, from the southeast of Mexico to the central region of Argentina. It shows good adaptability to different environments and artificial diets, as well as being resistant to handling required for commercial purposes (BALDISSEROTTO \& RADÜNZ NETO, 2004). The majority of the diseases reported in silver catfish farms are related to bacterial pathogens, and more specifically to the genus Aeromonas (BALDISSEROTTO \& RADÜNZ NETO, 2004; BARCELLOS et al., 2008). Furthermore, it has been shown that Aeromonas hydrophila and Citrobacter freundii, were the cause of fish injuries and mortality of naturally infected silver catfish, and Raoultella ornithinolytica was the cause of human intoxication by histamine due to the consumption of contaminated fish (KANKI et al., 2002; BANDEIRA JUNIOR et al., 2017).

Essential oils (EOs) isolated from plants are known for their antimicrobial properties. Specifically, their use against bacteria known to infect fish has been reported (BANDEIRA JUNIOR et al., 2017). The antimicrobial properties of a range of EOs have been studied against a range of microorganisms. These EOs included those obtained from the species Achyrocline satureioides (popularly known as "macela"), Aniba parviflora ("macacaporanga"), Aniba rosaeodora ("pau-rosa"), Anthemis nobilis ("Roman chamomile"), Conobea scoparioides ("pataqueira"), Cupressus sempervirens ("Italian cypress"), Illicium verum ("star anise"), Lippia origanoides ("alecrim-d'Angola"), and Melaleuca alternifolia ("tea tree") (WESELER et al., 2005; GONZÁLEZ \& MARIOLI, 2010; ROSATO et al., 2010; MONCAYO, 2012; AL-SNAFI, 2016; SILVA et al., 2016; IBRAHIM et al., 2017; NIKOLIĆ et al., 2017; PERERA et al., 2017). One study reported the in vivo antibacterial activity of $L$. origanoides EO against an experimentally induced $A$. hydrophila infection in tambaqui (Colossoma macropomum) (OLIVEIRA et al., 2018). Despite this, there are few studies investigating the effect of these EOs against bacteria isolated from fish. Therefore, the aim of this study was to evaluate the in vitro antibacterial activity of EOs against $A$. hydrophila, $C$. freundii, and $R$. ornithinolytica isolated from fish, and to further evaluate the in vivo antibacterial activity of the EO $L$. origanoides, against experimentally induced $A$. hydrophila infection in silver catfish.

\section{MATERIALS AND METHODS}

\section{Clinical isolates}

The strains A. hydrophila MF 372510 , C. freundii $\mathrm{MF} 565839$, and $R$. ornithinolytica $\mathrm{MF}$
372511 have been previously isolated from naturally infected juvenile silver catfish obtained from local fish farm (BANDEIRA JUNIOR et al., 2017). The bacteria were isolated from kidneys and skin lesions of naturally diseased fish and plated on blood and MacConkey agar. After $48 \mathrm{~h}\left(37^{\circ} \mathrm{C}\right)$ of incubation bacterial growth was observed and the colonies were submitted to gram staining and biochemical tests for presumptive identification (QUINN, 1994). The DNA from single colonies was extracted by boiling method. Molecular identification was obtained by analyzing the partial sequence ( $\sim 1400$ base pairs) of the 16S rRNA gene amplified with universal primers (FREDRICKS \& RELMAN, 1998). The PCR product were sequenced by ACT Gene Molecular Analysis (Centro de Biotecnologia, UFRGS, Brazil) using the automatic sequencer ABI-PRISM 3100 genetic analyzer (Applied Biosystems). Sequences were analyzed and their consensus sequences were assembled using $4 \mathrm{~s}$ Staden package programs (STADEN et al., 2000). In order to compare the consensus sequence ( $\sim 1400 \mathrm{bp})$ with other sequences available on GenBank database, BLASTN tool was performed. The closest relative $16 \mathrm{~S}$ rRNA sequences were used for the bacterial identification.

\section{Essential oils}

The EOs were obtained as follows: $A$. nobilis EO was purchased from Ferquima $^{\mathrm{TM}}$ (São Paulo, Brazil), C. sempervirens, I. verum, and $M$. alternifolia EOs were purchased from Vimontti ${ }^{\mathrm{TM}}$ (Santa Maria, Brazil), A. satureoides EO was purchased from Mundo dos Óleos ${ }^{\mathrm{TM}}$ (Brasília, Brazil), and A. parviflora, A. roseadora, C. scoparioides, and L. origanoides EOs were extracted from the dried leaves of the plants (forced air circulation oven at $40{ }^{\circ} \mathrm{C}$ for $24 \mathrm{~h}$ ) by hydro-distillation for $2 \mathrm{~h}$ using a Clevenger-type apparatus. The analysis of the chemical components of $L$. origanoides EO was determined by gas chromatography-mass spectrometry (GCMS) using a Shimadzu GC-17 AAF, V3, 230 LV apparatus, according to BALDISSERA et al. (2017). The five major constituents were carvacrol (40.73\%), $\rho$-cimene $(13.63 \%)$, thymol $(8.19 \%), \gamma$-terpinene $(5.43 \%)$, and $\beta$-linalool (4.19\%).

Minimum inhibitory concentration (MIC) and minimum bactericidal concentration $(M B C)$ assays

Three clinical isolates (A. hydrophila MF 372510, C. freundii MF 565839, and $R$. ornithinolytica MF 372511) were used for the MIC and MBC tests. These tests were conducted using the microdilution method, in accordance with the guidelines of the 
Clinical \& Laboratory Standards Institute (CLSI, 2014). The EOs were diluted in $96 \%$ ethanol and incorporated into Mueller Hinton broth (Himedia Laboratories, Mumbai, India) in serial dilutions, from the concentration 6.4 to the concentration $0.0125 \mathrm{mg}$ $\mathrm{mL}^{-1}$, in triplicate. The bacterial inoculum at $1 \times 10^{8}$ $\mathrm{CFU} \mathrm{mL}^{-1}\left(\mathrm{OD}_{600} 0.15\right)$ was prepared in a saline solution from cultures grown on Mueller Hinton agar (MHA) (Himedia Laboratories, Mumbai, India); for $24 \mathrm{~h}$ at $28^{\circ} \mathrm{C}$. Ten microliters $\left(1 \times 10^{5} \mathrm{CFU}\right)$ of inoculum was added to each well containing the EOs. Microplates were then incubated at $28^{\circ} \mathrm{C}$ for $24 \mathrm{~h}$ under aerobic conditions for MIC determinations, with the lowest concentration for each of the EOs that inhibited bacterial growth defined as the MIC. Ten microliters of the resazurin dye $(0.1 \%$ solution) was added in each well as a visual indicator of the MIC. The same procedure was performed with an ethanol control. Values of MBC were obtained by re-plating 10 $\mu \mathrm{L}$ of each bacterial culture into MHA $\left(28^{\circ} \mathrm{C} / 24 \mathrm{~h}\right)$, with the lowest concentration for each of the EOs showing no growth defined as the MBC.

\section{Animals and water quality parameters}

Apparently healthy (no external signs of lesions) juveniles silver catfish $(\mathrm{n}=120,10 \pm 2 \mathrm{~cm}$, $9 \pm 1 \mathrm{~g})$ were obtained from a local fish farm and acclimatized for 1 week in $250 \mathrm{~L}$ tanks, for use in the in vivo experiment. The fish were fed twice a day with an extruded commercial feed, $1.7 \mathrm{~mm}$ in size (Supra ${ }^{\mathrm{TM}}$ Juvenil, $46 \%$ protein). Food and feces that had accumulated at the bottom of tanks were removed daily, and water renewed to $25 \%$ every two days. The following water quality parameters were maintained, temperature $20 \pm 1^{\circ} \mathrm{C}, \mathrm{pH} 7.3 \pm 0.5$, dissolved oxygen $6.0 \pm 0.5 \mathrm{mg} \mathrm{L}^{-1}$ and a total ammonia concentration of $<0.5 \mathrm{mg} \mathrm{L}^{-1}$.

\section{In vivo experiment}

Fish were assigned into ten groups, each with twelve animals $(n=12)$. These groups were: uninfected (negative control), florfenicol (Maxflor ${ }^{\mathrm{TM}} 40 \%$ ) uninfected, ethanol uninfected, L. origanoides $\mathrm{EO} 2.5 \mu \mathrm{L}$ $\mathrm{L}^{-1}$ uninfected, L. origanoides EO $5.0 \mu \mathrm{L} \mathrm{L}^{-1}$ uninfected, infected (positive control), florfenicol infected, ethanol infected, $L$. origanoides EO $2.5 \mu \mathrm{L} \mathrm{L}^{-1}$ infected, and L. origanoides EO $5.0 \mu \mathrm{L} \mathrm{L}^{-1}$ infected. Concentrations greater than $5.0 \mu \mathrm{LL}^{-1}$ caused sedation to the animals, so this was the maximum $L$. origanoides EO concentration used. Additionally, the florfenicol concentration used (4.3 $\mathrm{mg} \mathrm{L}^{-1}$ ) was calculated to be equivalent to the highest $L$. origanoides EO concentration $\left(5 \mu \mathrm{L} \mathrm{L}^{-1}\right)$ based on oil density $\left(0.86 \mathrm{~g} \mathrm{~mL}^{-1}\right)$. As the EOs were diluted in ethanol (1:10), a group containing the highest concentration of ethanol used $\left(45 \mu \mathrm{L} \mathrm{L}^{-1}\right)$ was added.

For the inoculum, A. hydrophila $\mathrm{MF}$ 372510 was grown on MHA. The inoculum was prepared for the infection model in sterile saline $(\mathrm{NaCl} 0.9 \%)$ with the turbidity adjusted to an of

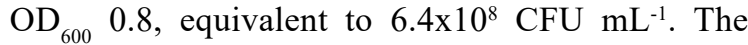
uninfected groups were inoculated intramuscularly into the right dorsal region with $100 \mu \mathrm{L}$ of sterile saline, while the infected groups were inoculated with $100 \mu \mathrm{L}$ of the inoculum, according to methods previously described (BANDEIRA JUNIOR et al., 2018a). The inoculated fish were distributed into 30 $\mathrm{L}$ tanks and submitted to daily baths of $1 \mathrm{~h}$, with the different testing solutions, for 4-days, consecutively. After inoculation, the viability of each of the fish was verified daily for 30 days to observe acute and chronic infection as well as death.

\section{Statistical analysis}

Regarding the longevity calculation, the Shapiro-Wilk and Levene tests were used to verify the normality and homogeneity of the variances, and a two-way analysis of variance followed by the Tukey's test were performed to verify differences between groups, and $F$ and $p$ values were shown only if $p<0.05$. The statistical analysis was performed considering the tank as experimental unit, and the fish as observational unit.

\section{RESULTS}

EOs showed antibacterial activity against the fish pathogens

In this study it was reported that the MICs were quite similar to the MBCs, highlighting that most of these EOs were more bactericidal than bacteriostatic. However, there are exceptions (Aniba parviflora EO against $A$. hydrophila and $C$. freundii, Illicium verum, and Melaleuca alternifolia EOs against $A$. hydrophila, and the latter against $R$. ornithinolytica) (Table 1). The L. origanoides EO was the most effective, with antibacterial activity against the three tested strains observed, with MICs ranging from 0.2 to $0.8 \mathrm{mg}$ $\mathrm{mL}^{-1}$. The $C$. scoparioides EO showed antibacterial activity against $A$. hydrophila with a MIC and MBC of $0.2 \mathrm{mg} \mathrm{mL}^{-1}$, but weak activity against $C$. freundii and $R$. ornithinolytica. The A. parviflora and $A$. rosaeodora EOs presented weak antibacterial activity against the three strains, with MICs ranging from 0.8 to $3.2 \mathrm{mg} \mathrm{mL}^{-1}$. Additionally, the $A$. nobilis, I. verum, and $M$. alternifolia EOs presented weak antibacterial activity against $A$. hydrophila and did not show any 
Table 1 - Minimum inhibitory concentrations (MICs) and minimum bactericidal concentrations (MBCs) of EOs against bacteria isolated from fish.

\begin{tabular}{|c|c|c|c|c|c|c|}
\hline & \multicolumn{2}{|c|}{$\begin{array}{c}\text { Aeromonas hydrophila } \\
\text { MF } 372510\end{array}$} & \multicolumn{2}{|c|}{$\begin{array}{l}\text { Citrobacter freundii } \\
\text { MF } 565839\end{array}$} & \multicolumn{2}{|c|}{$\begin{array}{c}\text { Raoultella ornithinolytica } \\
\text { MF } 372511\end{array}$} \\
\hline & $\begin{array}{c}\mathrm{MIC} \\
\mathrm{mg} \mathrm{mL}^{-1}\end{array}$ & $\begin{array}{c}\mathrm{MBC} \\
\mathrm{mg} \mathrm{mL}^{-1}\end{array}$ & $\begin{array}{c}\mathrm{MIC} \\
\mathrm{mg} \mathrm{mL}^{-1}\end{array}$ & $\begin{array}{c}\mathrm{MBC} \\
\mathrm{mg} \mathrm{mL}^{-1}\end{array}$ & $\begin{array}{c}\mathrm{MIC} \\
\mathrm{mg} \mathrm{mL}^{-1}\end{array}$ & $\begin{array}{c}\mathrm{MBC} \\
\mathrm{mg} \mathrm{mL}^{-1}\end{array}$ \\
\hline $\begin{array}{l}\text { Achyrocline } \\
\text { satureioides }\end{array}$ & $>6.4$ & $>6.4$ & $>6.4$ & $>6.4$ & $>6.4$ & $>6.4$ \\
\hline Aniba parviflora & 0.8 & 1.6 & 3.2 & 6.4 & 3.2 & 3.2 \\
\hline Aniba rosaeodora & 3.2 & 3.2 & 3.2 & 3.2 & 3.2 & 3.2 \\
\hline Anthemis nobilis & 6.4 & 6.4 & $>6.4$ & $>6.4$ & $>6.4$ & $>6.4$ \\
\hline Conobea scoparioides & 0.2 & 0.2 & 3.2 & 3.2 & 3.2 & 3.2 \\
\hline Cupressus sempervirens & $>6.4$ & $>6.4$ & $>6.4$ & $>6.4$ & $>6.4$ & $>6.4$ \\
\hline Illicium verum & 1.6 & 3.2 & $>6.4$ & $>6.4$ & $>6.4$ & $>6.4$ \\
\hline Lippia origanoides & 0.2 & 0.2 & 0.8 & 0.8 & 0.8 & 0.8 \\
\hline Melaleuca alternifolia & 3.2 & 6.4 & $>6.4$ & $>6.4$ & 6.4 & $>6.4$ \\
\hline
\end{tabular}

activity against $C$. freundii and $R$. ornithinolytica. Furthermore, the $A$. satureioides and $C$. sempervirens EOs did not present any activity against all tested strains. Of the strains, $A$. hydrophila was found to be the most sensitive, with antibacterial activity against it by majority of the EOs tested.

In vivo testing of L. origanoides EO antibacterial activity

Based on the screening results of the in vitro study of the antibacterial effect of EOs, L. origanoides EO was selected for testing against experimentally induced $A$. hydrophila infection in silver catfish.

A significant interaction was observed between $A$. hydrophila infection and $L$. origanoides treatment $(F \quad 1,0=4.41 ; p=0.001)$. No uninfected fish died during the experimental period; however, $100 \%$ of the infected control group with no treatment died. A significant increase to animal longevity was observed in the groups treated with florfenicol and $L$. origanoides EO $5.0 \mu \mathrm{L} \mathrm{L}^{-1}$, compared to the non-treated infected control group. Fish treated with $L$. origanoides EO 5.0 $\mu \mathrm{L} \mathrm{L}^{-1}$ showed a similar longevity to the infected group treated with florfenicol (Table 2). However, the L. origanoides EO $5.0 \mu \mathrm{L} \mathrm{L}^{-1}$ treatment obtained the best results with a $58.33 \%$ survival rate, with treatment with florfenicol and $L$. origanoides EO $2.5 \mu \mathrm{L} \mathrm{L}^{-1}$ achieving a $25 \%$ survival rate (Table 2 ).

\section{DISCUSSION}

Bacterial diseases are considered as obstacles to the development of aquaculture, with a global estimate of disease losses in the range of several billion US\$ per year. To control these diseases, large amounts of antibiotics are used, which often results in the development of resistance in aquaculture pathogens (DEFOIRDT, 2014). In this sense, the need arises for the discovery of new substances with activity against fish pathogenic bacteria. Among these substances, we highlighted the EOs.

In relation to the MIC and MBC assay, the $A$. hydrophila strain was more sensitive to A parviflora, $A$. nobilis, C. scoparioides, I. verum, L. origanoides, and $M$. alternifolia EOs when compared to C. freundii and $R$. ornithinolytica strains. BANDEIRA JUNIOR et al. (2018b) also demonstrated that the $A$. hydrophila strain was more sensitive to phytochemicals than $C$. freundii and $R$. ornithinolytica strains. However, the $A$. hydrophila strain was highly pathogenic in the in vivo test because it caused cutaneous ulcerations, hemorrhagic septicemia, and high mortality in experimentally infected silver catfish.

Previously, A. satureioides EO has been shown to be associated with antimicrobial activity against Paenibacillus larvae (GONZÁLEZ \& MARIOLI, 2010). In the present study, this particular plant EO did not present activity against the three tested strains. Furthermore, the $C$. sempervirens EO has been previously shown to have activity against a number of different bacteria, specifically the human pathogens Streptococcus pyogenes, Pseudomonas aeruginosa, and Shigella boydii (IBRAHIM et al., 2017). In addition, the $C$. sempervirens EO also showed activity against several pathogenic bacteria for both animals and plants (MAZARI et al., 2010; 
Table 2 - Mortality, longevity, and therapeutic success using L. origanoides EO to treat silver catfish experimentally infected with A. hydrophila MF 372510 . Asterisk $\left(^{*}\right)$ indicates a significant difference between the infected and the uninfected fish submitted to the same treatment. Different letters (a-c) indicate significant differences between infected groups.

\begin{tabular}{lccc}
\hline Groups & Mortality & Longevity (days) & Therapeutic success $(\%)$ \\
\hline Uninfected (negative control) & $0 / 12$ & $30 \pm 0.0$ \\
Uninfected + florfenicol & $0 / 12$ & $30 \pm 0.0$ & - \\
Uninfected + ethanol & $0 / 12$ & $30 \pm 0.0$ & - \\
Uninfected + L. origanoides EO $2.5 \mu \mathrm{L} \mathrm{L}^{-1}$ & $0 / 12$ & $30 \pm 0.0$ & - \\
Uninfected + L. origanoides EO $5.0 \mu \mathrm{L} \mathrm{L}^{-1}$ & $0 / 12$ & $30 \pm 0.0$ & - \\
Infected (positive control) & $12 / 12$ & $9.33 \pm 1.63^{\mathrm{c}^{*}}$ & $26.5 \pm 0.88^{\mathrm{a}}$ \\
Infected + florfenicol & $9 / 12$ & $10.33 \pm 1.55^{\mathrm{c}^{*}}$ & - \\
Infected + ethanol & $11 / 12$ & $15.92 \pm 3.10^{\mathrm{bc}^{*}}$ & 25 \\
Infected + L. origanoides EO $2.5 \mu \mathrm{L} \mathrm{L}^{-1}$ & $9 / 12$ & $19.25 \pm 3.85^{\mathrm{ab}}$ & 25 \\
\hline Infected + L. origanoides EO $5.0 \mu \mathrm{L} \mathrm{L}^{-1}$ & $5 / 12$ & 58.33 \\
\hline
\end{tabular}

BADAWY \& ABDELGALEIL, 2014). However, again in the present study this EO showed no antibacterial activity against fish pathogens.

A. parviflora $\mathrm{EO}$ has been previously shown to have activity against $E$. coli and Bacillus cereus strains (SILVA et al., 2016), but in the present study it was only reported to have weak activity against the three strains tested. Furthermore, an under studied EO $C$. scoparioides has previously been shown to have better activity against Gram-positive bacteria compared to Gram-negative bacteria (MONCAYO, 2012); however, in the present study C. scoparioides EO was reported to have antibacterial activity against $A$. hydrophila, but weak activity against $C$. freundii and $R$. ornithinolytica. Combination of $A$. rosaeodora EO with gentamicin has been established to have a synergistic effect against several strains of both Gram-positive and Gram-negative bacteria, but especially Acinetobacter baumannii (ROSATO et al., 2010). However, A. rosaeodora EO had only weak activity against the tested strains in the present study, possibly due to the strains being Gram-negative bacteria, which are known to be more resistant to EOs (CHAO et al., 2011).

The A. nobilis EO have been established to have activity against Gram-positive and Gramnegative bacteria (AL-SNAFI, 2016). Also, I. verum EO has been shown to have antibacterial activity against Helicobacter pylori (WESELER et al., 2005). However, this EO has been shown to not be effective against oral bacterial pathogens (TARDUGNO et al., 2018). Furthermore, the $M$. alternifolia EO has been previously established to have activity against $S$. aureus as well as a number of Streptococcus spp. (NIKOLIĆ et al., 2017). In addition, this particular EO has been proven to be effective in the treatment of skin infections caused by Propionibacterium acnes and oral infections caused by Streptococcus mutans and Lactobacillus spp. (WULANSARI et al., 2017; TARDUGNO et al., 2018). Though in the present study, all these EOs, only presented weak antibacterial activity against A. hydrophila and did not demonstrate any activity against the two other tested bacteria.

In the present study, the most effective EO was reported to be L. origanoides EO with antibacterial activity against all three tested strains. Previously, L. origanoides EO has been shown to have activity against Gram-positive bacteria such as $S$. aureus, E. faecalis, and Bacillus subtilis, and Gram-negative bacteria such as E. coli, Salmonella thyphimurium, Shigella sonnei, and Pseudomonas spp. (CHATAING et al., 2012; PERERA et al., 2017). Due to the high in vitro antimicrobial efficacy of $L$. origanoides EO, this oil was then selected for an in vivo investigation, in which infection was experimentally induced with $A$. hydrophila in silver catfish. Strain A. hydrophila MF 372510 was selected for the in vivo assay because it was isolated from naturally infected silver catfish, which had cutaneous ulcers, hemorrhagic septicemia, and high mortality (BANDEIRA JUNIOR et al., 2017). It was reported that the most effective concentration of EO for the treatment of A. hydrophila was 5.0 $\mu \mathrm{L} \mathrm{L}{ }^{-1}$. Another study reported that tambaquis experimentally infected with $A$. hydrophila had a high survival rate $(79.2 \%)$ after therapeutic bath with $10 \mathrm{mg} \mathrm{L}^{-1}$ of L. origanoides EO (OLIVEIRA 
et al., 2018).

In our previous study, a screening of antibiotic susceptibility was performed and the multiple antibiotic resistance was calculated, where the bacteria used in this research were reported as multidrug-resistant (BANDEIRA JUNIOR et al., 2018b). Therefore, these results suggested that this EO may be a viable alternative for the treatment of infections by pathogens in fish, especially those caused by $A$. hydrophila resistant to conventional antimicrobials. It is thought that the bactericidal action is due to the bacterial membrane being disrupted by the lipophilic constituents of the EO (ALVIANO \& ALVIANO, 2009). Recently it has been demonstrated that an $L$. origanoides EO, with a similar composition to what was used in the present study, showed MIC and MBC values of $2.5 \mathrm{mg} \mathrm{mL}^{-1}$ against $A$. hydrophila (MAJOLO et al., 2017). It was suggested that the mechanism may be associated to the rupture of the cell membrane and the subsequent release of liposaccharide, leading to an increase permeability to adenosine triphosphate. In the present study the main constituent of $L$. origanoides EO was reported to be carvacrol, comprising 40.73 $\%$ of the composition. Previously, carvacrol has been shown to have the ability to cause the A. hydrophila membrane to rupture, causing bacterial death, reducing the mortality of channel catfish (Ictalurus punctatus) infected by this bacterium (ZHENG et al., 2009; SOUSA et al., 2015). Therefore, it is most likely carvacrol playing a key role in the antibacterial activity for L. origanoides EO reported in the present study; however, synergistic activity with other compounds of this EO is also possible.

There is a shortage of treatments for bacterial infections in fish, with oxytetracycline, florfenicol, and sulfadimethoxine/ormetoprim being the only antimicrobials approved by the Food and Drug Administration for use in aquaculture (FDA, 2014). This makes treatment of $A$. hydrophila infection in fish a challenge, mortality remaining high as a consequence of cutaneous ulcers and hemorrhagic septicemia, even with treatment using conventional antimicrobials (BARCELLOS et al., 2008; NGUGI et al., 2015). Therefore, the L. origanoides EO, with a therapeutic success of $58.33 \%$ in improving the lifespan of fish infected with $A$. hydrophila, is a promising alternative to be used in the treatment of this infection.

\section{CONCLUSION}

The L. origanoides EO had the highest in vitro antibacterial activity, and in vivo, this EO showed the ability to have a therapeutic effect against infection by $A$. hydrophila with lower mortality of the fish. Therefore, L. origanoides EO represented a possible new alternative in the treatment of infections caused by $A$. hydrophila in the fish population.

\section{ACKNOWLEDGEMENTS}

We would like to thank INCT-ADAPTA 2 (Conselho Nacional de Desenvolvimento Científico e Tecnológico/Fundação de Amparo à Pesquisa no Estado do Amazonas). B. Baldisserotto is funded by a CNPq (Conselho Nacional de Desenvolvimento Científico e Tecnológico) research fellowship and G. Bandeira Junior, C.F. Souza and M.D. Baldissera are funded by CAPES (Coordenação de Aperfeiçoamento de Pessoal de Nível Superior, finance code 001) $\mathrm{PhD}$ fellowships. S.N. Descovi received a FAPERGS (Fundação de Amparo à Pesquisa do Estado do Rio Grande do Sul) undergraduate fellowship.

\section{BIOETHICS AND BIOSSECURITY COMMITTEE APPROVAL}

All experimental protocols involving animals was approved by the Ethics Commission for Animal Use (CEUA) at Universidade Federal de Santa Maria (UFSM), Santa Maria, RS, Brazil (Protocol 74/2014-CEUA) and met the guidelines of Conselho Nacional de Controle de Experimentação Animal (CONCEA).

\section{DECLARATION OF CONFLICT OF INTERESTS}

The authors declare no conflict of interest. The founding sponsors had no role in the design of the study; in the collection, analyses, or interpretation of data; in the writing of the manuscript, and in the decision to publish the results.

\section{AUTHORS' CONTRIBUTIONS}

All authors contributed equally to the manuscript design and writing. All authors critically revised the manuscript and approved the final version.

\section{REFERENCES}

AL-SNAFI, A.E. Medical importance of Anthemis nobilis (Chamaemelum nobile) - a review. Asian Journal of Pharmaceutical Science \& Technology, v.6, n.2, p.89-95, 2016. Available from: $<$ https://pdfs.semanticscholar.org/9b44/33c7197e c9a911483036bbb77a75d808abba.pdf>. Accessed: Mar. 27, 2019.

ALVIANO, D.S.; ALVIANO, C.S. Plant extracts: search for new alternatives to treat microbial diseases. Current Pharmaceutical Biotechnology, v.10, n.1, p.106-121, jan., 2009. Available from: $<$ https://www.ncbi.nlm.nih.gov/pubmed/19149593>. Accessed: Jan. 11, 2019. doi: 10.2174/138920109787048607.

BADAWY, M.E.I.; ABDELGALEIL, S.A.M. Composition and antimicrobial activity of essential oils isolated from Egyptian plants against plant pathogenic bacteria and fungi. Industrial Crops and Products, v.52, p.776-782, Jan., 2014. Available from: <https:// www.sciencedirect.com/science/article/pii/S0926669013006808>. Accessed: Jan. 10, 2019. doi: 10.1016/j.indcrop.2013.12.003. 
BAKER, M.R. et al. Review of factors influencing stress hormones in fish and wildlife. Journal for Nature Conservation, v.21, n.5, p.309-318, Oct., 2013. Available from: $<$ https://www.sciencedirect. com/science/article/pii/S1617138113000368>. Accessed: Jan. 10, 2019. doi: 10.1016/j.jnc.2013.03.003.

BALDISSERA, M.D. et al. Trypanocidal action of Lippia alba and Lippia origanoides essential oils against Trypanosoma evansi in vitro and in vivo used mice as experimental model. Journal of Parasitic Diseases, v.41, n.2, p.345-351, Jun., 2017. Available from: $<$ https://www.ncbi.nlm.nih.gov/pubmed/28615837>. Accessed: Jan. 12, 2019. doi: 10.1007/s12639-016-0800-7.

BALDISSEROTTO, B.; RADÜNZ NETO, J. Criação de jundiá. Santa Maria : Editora UFSM, 2004. 232p.

BANDEIRA JUNIOR, G. et al. Potential uses of Ocimum gratissimum and Hesperozygis ringens essential oils in aquaculture. Industrial Crops and Products, v.97, p.484-491, Mar., 2017. Available from: <https:// www.sciencedirect.com/science/article/pii/S0926669016308706>. Accessed: Jan. 11, 2019. doi: 10.1016/j.indcrop.2016.12.040.

BANDEIRA JUNIOR, G. et al. Citrobacter freundii infection in silver catfish (Rhamdia quelen): hematological and histological alterations. Microbial Pathogenesis, v.125, p.276-280, Dec., 2018a. Available from: <https://www.sciencedirect.com/science/ article/pii/S0882401018313597>. Accessed: Jan. 12, 2019. doi: 10.1016/j.micpath.2018.09.038.

BANDEIRA JUNIOR, G. et al. Antibacterial potential of phytochemicals alone or in combination with antimicrobials against fish pathogenic bacteria. Journal of Applied Microbiology, v.125, n.3, p.655-665, Sep., 2018b. Available from: <https://www.ncbi. nlm.nih.gov/pubmed/29741243>. Accessed: Jan. 10, 2019. doi: 10.1111/jam.13906.

BARCELLOS, L.J.G. et al. Aeromonas hydrophila in Rhamdia quelen: macroscopic and microscopic aspect of the lesions and antibiotic resistence profiles. Boletim do Instituto de Pesca, v.34, n.3, p.355-363, 2008. Available from: <https://www.pesca. agricultura.sp.gov.br/34_3_355-363.pdf $>$. Accessed: Jan. 12, 2019.

CHAO, S.C. et al. Screening for inhibitory activity of essential oils on selected bacteria, fungi and viruses. Journal of Essential Oil Research, v.12, n.5, p.639-649, Dec., 2011. Available from: <https://www.tandfonline.com/doi/abs/10.10 80/10412905.2000.9712177>. Accessed: Jan. 12, 2019. doi: 10.1080/10412905.2000.9712177.

CHATAING, B. et al. Chemical composition and bioactivity on bacteria and fungi of the essential oil from Lippia origanoides H.B.K. Journal of Essential Oil Bearing Plants, v.15, n.3, p.454-460, 2012. Available from: <https://www.tandfonline. com/doi/abs/10.1080/0972060X.2012.10644072?tab=permissio ns\&scroll=top\#metrics-content $>$. Accessed: Jan. 12, 2019. doi: 10.1080/0972060X.2012.10644072.

CLSI. Methods for broth dilution susceptibility testing of bacteria isolated from aquatic animals, approved guideline, 2nd ed. Wayne : Clinical and Laboratory Standards Institute, 2014.

DEFOIRDT, T. Virulence mechanisms of bacterial aquaculture pathogens and antivirulence therapy for aquaculture. Reviews in Aquaculture, v.6, n.2, p.100-114, Jun., 2014. Available from: $<$ https://onlinelibrary.wiley.com/doi/full/10.1111/raq.12030>. Accessed: Jan. 11, 2019. doi: 10.1111/raq.12030.
EL-NAHHAL, Y. et al. Toxicological data of some antiobiotics and pesticides to fish, mosquitoes, cyanobacterial mats and to plants. Data in Brief, v.6, p.871-880, Feb., 2016. Available from: $<$ https:// www.ncbi.nlm.nih.gov/pubmed/26937464>. Accessed: Jan. 12, 2019. doi: 10.1016/j.dib.2016.01.051.

FDA. Approved Drugs. USA : Food and Drug Administration Department of Health and Human Services, 2014.

FREDRICKS, D.N.; RELMAN, D.A. Improved amplification of microbial DNA from blood cultures by removal of the PCR inhibitor sodium polyanetholesulfonate. Journal of Clinical Microbiology, v.36, n.10, p.2810-2816, Oct., 1998. Available from: <https://jcm.asm.org/content/36/10/2810.long>. Accessed: Mar. 19, 2019.

GONZÁLEZ, M.J.; MARIOLI, J.M. Antibacterial activity of water extracts and essential oils of various aromatic plants against Paenibacillus larvae, the causative agent of American Foulbrood. Journal of Invertebrate Pathology, v.104, n.3, p.209213, Jul., 2010. Available from: <https://www.ncbi.nlm.nih.gov/ pubmed/20398671>. Accessed: Jan. 11, 2019. doi: 10.1016/j. jip.2010.04.005.

GRENNI, P. et al. Ecological effects of antibiotics on natural ecossystems: a review. Microchemical Journal, v.136, p.2539, Jan., 2018. Available from: <https://www.sciencedirect.com/ science/article/pii/S0026265X17301108>. Accessed: Jan. 11, 2019. doi: 10.1016/j.microc.2017.02.006.

IBRAHIM, T.A. et al. Chemical composition and antimicrobial activities of essential oils of some coniferous plants cultivated in Egypt. Iranian Journal of Pharmaceutical Research, v.16, n.1, p.328-337, 2017. Available from: <https://www.ncbi.nlm.nih.gov/ pubmed/28496486>. Accessed: Jan. 10, 2019.

KANKI, M. et al. Klebsiella pneumoniae produces no histamine: Raoultella planticola and Raoultella omithinolytica strains are histamine producers. Applied and Environmental Microbiology, v.68, n.7, p.3462-3466, Jul., 2002. Available from: <https://www. ncbi.nlm.nih.gov/pmc/articles/PMC126807/>. Accessed: Jan. 11, 2019. doi: 10.1128/AEM.68.7.3462-3466.2002.

MAJOLO, C. et al. Chemical composition of Lippia spp. essential oil and antimicrobial activity against Aeromonas hydrophila. Aquaculture Research, v.48, n.5, p.2380-2387, May, 2017. Available from: $<$ https://onlinelibrary.wiley.com/doi/full/10.1111/ are.13073>. Accessed: Jan. 12, 2019. doi: 10.1111/are.13073.

MAZARI, K. et al. Chemical composition and antimicrobial activity of essential oils isolated from Algerian Juniperus phoenicea L. and Cupressus sempervirens L. Journal of Medicinal Plants Research, v.4, n.10, p.959-964, May, 2010. Available from: <http://www.academicjournals.org/app/webroot/ article/article1380705668_Mazari\%20et\%20al.pdf>. Accessed: Jan. 12, 2019. doi: 10.5897/JMPR10.169.

MONCAYO, M.Z. Antibacterial activity of the essential oil of the Conobea scoparioides compared with five bacterial strains from clinical interest in Colombia. Bogotá : Universidad del Rosario, 2012. 65p. Available from: <http://repository. urosario.edu.co/bitstream/handle/10336/3166/63547301-2012. pdf? sequence=1>. Accessed: Jan. 10, 2019.

NGUGI, C.C. et al. Effects of dietary administration of stinging nettle (Urtica dioica) on the growth performance, biochemical, hematological 
and immunological parameters in juvenile and adult Victoria Labeo (Labeo victorianus) challenged with Aeromonas hydrophila. Fish and Shellfish Immunology, v.44, n.2, p.533-541, jun., 2015. Available from: <https://www.ncbi.nlm.nih.gov/pubmed/25827627>. Accessed: Jan. 12, 2019. doi: 10.1016/j.fsi.2015.03.025.

NIKOLIĆ, M.M. et al. Antimicrobial synergism and cytotoxic properties of Citrus limon L., Piper nigrum L. and Melaleuca alternifolia (Maiden and Betche) Cheel essential oils. Journal of Pharmacy and Pharmacology, v.69, n.11, p.1606-1614, Nov., 2017. Available from: <https://www.ncbi.nlm.nih.gov/ pubmed/28815601>. Accessed: Jan. 10, 2019. doi: 10.1111/ jphp. 12792 .

OLIVEIRA, S.R.N. et al. Toxicity of Lippia origanoides essential oil in tambaqui (Colossoma macropomum) and its effect against Aeromonas hydrophila. Boletim do Instituto de Pesca, v.44, n.2, p.1-7, 2018. Available from: $<$ https:// ainfo.cnptia.embrapa.br/digital/bitstream/item/175607/1/ TOXICITY-OF-LIPPIA-ORIGANOIDES-ESSENTIALOIL-IN-TAMBAQUI.pdf>. Accessed: Mar. 19, 2019. doi: 10.20950/1678-2305.2018.346.

PERERA, W.H. et al. Essential oil constituents from high altitude Brazilian species with antimicrobial activity: Baccharis parvidentata Malag., Hyptis monticola Mart. ex Benth. and Lippia origanoides Kunth. Journal of Essential Oil Research, v.29, n.2, p.109-116, 2017. Available from: <https://www.tandfonline.com/ doi/abs/10.1080/10412905.2016.1210039>. Accessed: Jan. 11, 2019. doi: 10.1080/10412905.2016.1210039.

QUINN, P.J. Aeromonas, Plesiomonas and Vibrio species. In: QUINN, P.J. et al. Clinical Veterinary Microbiology. London : Wolfe Publishing, 1994. p.243-253.

ROSATO, A. et al. In vitro synergistic action of certain combinations of gentamicin and essential oils. Current Medicinal Chemistry, v.17, n.28, p.3289-3295, Jul., 2010. Available from: $<$ https://www.ncbi.nlm.nih.gov/pubmed/20666717>. Accessed: Jan. 11, 2019. doi: 10.2174/092986710792231996.

SILVA, J.K.R. et al. Antioxidant, antimicrobial, and cytotoxic properties of Aniba parviflora essential oils from the Amazon.
Natural Product Communications, v.11, n.2, p.1025-1028, Jul., 2016. Available from: <https://www.ncbi.nlm.nih.gov/m/ pubmed/30452187/>. Accessed: Jan. 10, 2019.

SOUSA, J.P. et al. Influence of carvacrol and 1,8-Cineole on cell viability, membrane integrity, and morphology of Aeromonas hydrophila cultivated in a vegetable-based broth. Journal of Food Protection, v.78, n.2, p.424-429, feb., 2015. Available from: $<$ https://www.ncbi.nlm.nih.gov/pubmed/25710162>. Accessed: Jan. 12, 2019. doi: 10.4315/0362-028X.JFP-14-242.

STADEN, R. et al. The Staden package, 1998. Methods in Molecular Biology, v.132, p.115-130, 2000. Available from: $<$ https://www.ncbi. nlm.nih.gov/pubmed/10547834>. Accessed: Mar. 19, 2019.

TARDUGNO, R. et al. Phytochemical composition and in vitro screening of the antimicrobial activity of essential oils on oral pathogenic bacteria. Natural Product Research, v.32, n.5, p.544-551, Mar., 2018. Available from: <https://www.ncbi. nlm.nih.gov/pubmed/28514868>. Accessed: Jan. 12, 2019. doi: 10.1080/14786419.2017.1329730.

WESELER, A. et al. A novel colorimetric broth microdilution method to determine the minimum inhibitory concentration (MIC) of antibiotics and essential oils against Helicobacter pylori. Pharmazie, v.60, n.7, p.498-502, aug., 2005. Available from: < https://www.ncbi. nlm.nih.gov/pubmed/16076074>. Accessed: Mar. 27, 2019.

WULANSARI, A. et al. Studies on the formulation, physical stability, and in vitro antibacterial activity of tea tree oil (Melaleuca alternifolia) nanoemulsion gel. International Journal of Applied Pharmaceutics, v.9, n.1, p.135-139, Oct., 2017. Available from: $<$ https://innovareacademics.in/journals/index.php/ijap/article/ view/23327/12865>. Accessed: Jan. 11, 2019. doi: 10.22159/ ijap.2017.v9s1.73_80.

ZHENG, Z.L. et al. Evaluation of oregano essential oil (Origanum heracleoticum L.) on growth, antioxidant effect and resistance against Aeromonas hydrophila in channel catfish (Ictalurus punctatus). Aquaculture, v.292, n.3-4, p.214-218, Jul., 2009. Available from: <https://www.sciencedirect.com/science/article/ abs/pii/S0044848609004037>. Accessed: Jan. 11, 2019. doi: 10.1016/j.aquaculture.2009.04.025. 